\title{
Street market saleswomen: strategies for the recognition of health needs
}

\author{
Mulheres feirantes: estratégias para o reconhecimento das necessidades de saúde \\ Mujeres feriantes: estrategias para el reconocimiento de las necesidades de salud
}

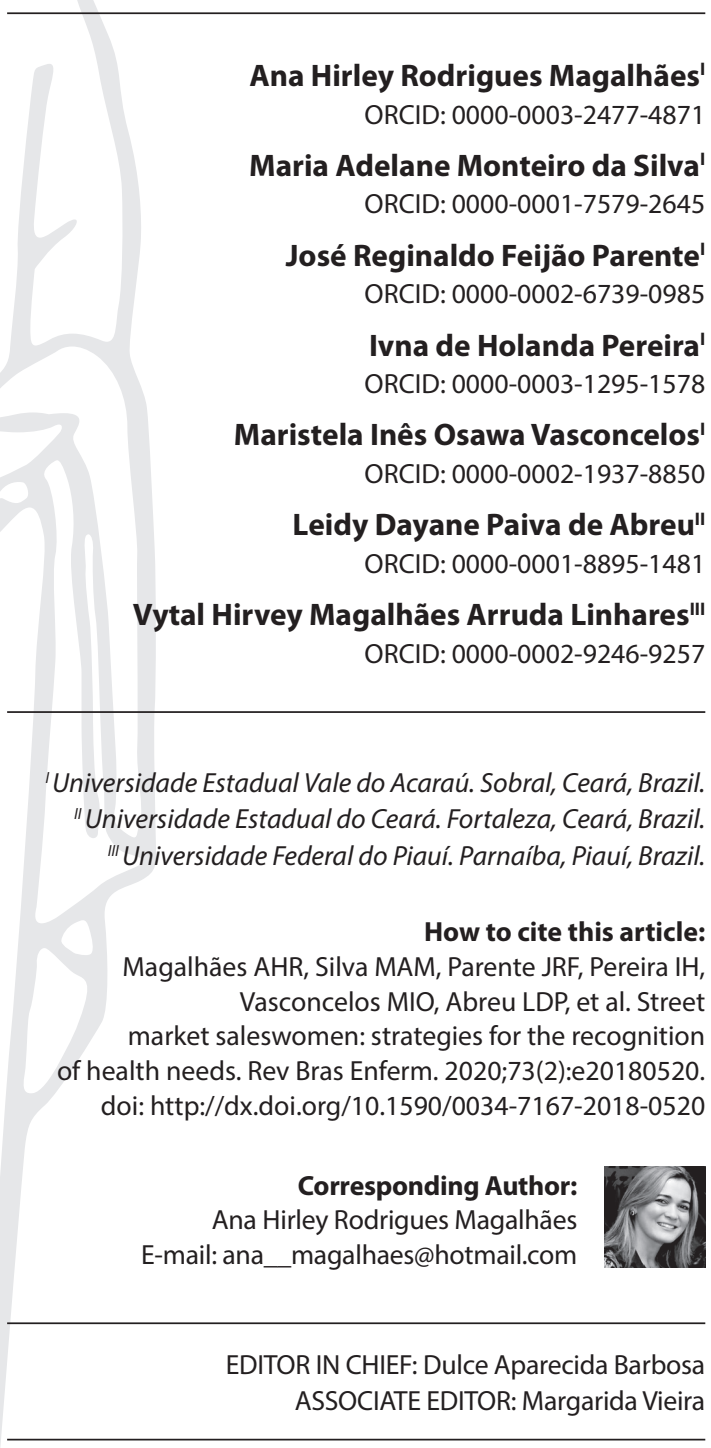

Submission: $06-30-2018$

Approval: 12-23-2018

\begin{abstract}
Objectives: to describe the strategies used by street market saleswomen to recognize their health needs. Methods: qualitative research, based on the Human Needs Theory The data were collected through semi-structured interviews, with the participation of 15 street market saleswomen. Content Analysis was used to interpret the results. Results: the following categories emerged: "Potentialities and challenges for addressing health needs", which reflect changes in attitudes and practices related to socially recognized behaviors as harmful, and changes in the work process; and "Popular practices in health care", which points out therapeutic alternatives for the resolution of health problems. Final considerations: the therapeutic choices of street market saleswomen are geared towards meeting their perceived health needs. While the minority of these women recognize their more complex health needs to satisfy it, it is necessary to overcome barriers and limitations in an ongoing way in their lives.

Descriptors: Women; Health Promotion; Health Services: Needs and Demand; Nursing Care; Health.
\end{abstract}

\section{RESUMO}

Objetivos: descrever as estratégias utilizadas por mulheres feirantes para reconhecimento de suas necessidades de saúde. Métodos: pesquisa qualitativa, fundamentada na Teoria das Necessidades Humanas. Os dados foram coletados por meio de entrevistas semiestruturadas, com a participação de 15 mulheres feirantes. Para a interpretação dos resultados, utilizou-se a Análise de Conteúdo. Resultados: emergiram as categorias temáticas: "Potencialidades e desafios para o enfrentamento das necessidades de saúde", que reflete modificações de atitudes e práticas relacionadas a comportamentos socialmente reconhecidos como prejudiciais, e mudanças no processo de trabalho; e "Práticas populares no cuidado à saúde", que aponta alternativas terapêuticas para a resolução dos problemas de saúde. Considerações finais: evidencia-se que as escolhas terapêuticas das feirantes são voltadas para o enfrentamento de suas necessidades de saúde percebidas. Embora a minoria dessas mulheres reconheça suas necessidades de saúde mais complexas, para satisfazê-la, é necessário superar barreiras e limitações de maneira contínua em suas vidas.

Descritores: Mulheres; Promoção da Saúde; Necessidades e Demandas de Serviços de Saúde; Cuidados de Enfermagem; Saúde.

\section{RESUMEN}

Objetivos: describir las estrategias utilizadas por las mujeres feriantes, para el reconocimiento de sus necesidades de salud. Métodos: pesquisa cualitativa, fundamentada en la Teoría de las Necesidades Humanas. Se colectaron los datos en entrevistas semiestructuradas. Participaron 15 mujeres feriantes. Se interpretaron los datos a través del análisis de contenido. Resultados: emergieron dos categorías temáticas: "Potencialidades y desafíos para el enfrentamiento de las necesidades de salud", que reflejan modificaciones de actitudes y prácticas relacionadas a comportamientos socialmente perjudiciales y cambios en el proceso de trabajo; y, "Prácticas populares en la atención a la salud", que apunta alternativas terapéuticas para la resolución de problemas de salud. Consideraciones finales: se concluyó que las selecciones terapéuticas de las feriantes se vuelcan al enfrentamiento de sus necesidades de salud percibidas, y, aunque la minoría de esas mujeres reconozca sus necesidades de salud más complejas, para satisfacerlas, hay que superar barreras y limitaciones continuamente en sus vidas.

Descriptores: Mujeres; Promoción de la Salud; Necesidades y Demandas de Servicios de Salud; Atención de Enfermería; Salud. 


\section{INTRODUCTION}

The insertion of women in the labor market was marked by confrontations with the prejudices that historically have affected and still affect women in various dimensions, including in relation to professional insertion. Faced with this, there are impacts on cultural and social relations, with changes in paradigms in society and in the family. In Brazil, the entry of women into the labor market occurs under the sign of inequality evidenced by the payment of lower wages, restricted access to social rights and obstacles created for professional growth ${ }^{(1)}$.

In this context, street markets have proven to be a place where women can enter the labor market with more freedom and autonomy, using their conversational skills to build and conquer their clientele. By not setting up as a formal business division, this space provides a new model of life in which street market saleswomen have the opportunity to have an income. They show that they are able to manage a small enterprise with a sense of self-realization and high self-esteem, to have their livelihoods acquired by their workforce and to be in tune with globalization and social, economic and urban transformations ${ }^{(2)}$.

On the other hand, this work also presents peculiar characteristics, characterized by variable monthly income, with low levels of decision-making power and control over salary, long hours with exposure to inadequate working conditions, such as standing for a long time; to move from side to side, inside boxing; do not have fixed hours for meals and do them in the work environment between one customer service and another, in addition to the absence of social guarantees and benefits. Such conditions may lead to the bio-psychic erosion of street market saleswomen, being a potential element of illness.

A recent review of studies with informal workers, including street market saleswomen, shows that in the Americas, these workers most commonly have common psychological disorders and repetitive strain injuries or musculoskeletal diseases. In this segment of workers, women predominate, a group that has not been studied in the aspects related to health and safety, which need to be analyzed, allowing a better understanding of the dimension and causality of this health problem $^{(3-4)}$.

Considering diseases as expressions of conflicts that are solved, a specific preventive action is not enough to combat them, but it is necessary to change the way of living, to produce and to relate to each other. Health struggle has aroused great cultural and social transformations and, in order to improve it, one cannot passively accept a reality that generates disease. If improper conditions can be modified, it is necessary to react and fight as an individual and groups of individuals ${ }^{(5)}$.

In this sense, in order to heal someone, it is necessary to increase the capacity of their autonomy, to improve the understanding of their own body, their illness, their relations with the social environment and, consequently, the capacity of each one to institute norms that increase the possibilities of survival, quality of life and coping with health needs ${ }^{(6)}$.

It is verified that researches developed with street market saleswomen are more focused on the entrepreneurship and focus of gender at work. Although there have been studies on the working and health conditions of the street market saleswomen ${ }^{(7-8)}$, few address the complexity and multidimensionality of the health needs of these informal workers; about how these people experience, think and perceive the world.

Given the gaps still existing in the scientific literature, the following guiding question is raised: "What strategies and challenges to address health needs in the daily work of street market saleswomen in a public market?"

Health needs, as well as other human needs, are socially and historically determined, and concern not only the conservation of life but the realization of a life project in which the individual progressively becomes human ${ }^{(6)}$.

Therefore, health services need to produce health care practices to encourage and broaden discussion and knowledge about the health needs of these women, in these life universes, placing Primary Health Care $(\mathrm{PHC})$ as coordinator and care in the social process capable of instrumentalizing the satisfaction of these needs. In this context, nurses work with social and humanistic relevance, because through their clinical practice, in an expanded perspective, these professionals have been developing care in health settings, in the various settings and public, as in the case of fair and street market saleswomen.

\section{OBJECTIVE}

To describe the strategies used by street market saleswomen to recognize their health needs.

\section{METHOD}

\section{Ethical aspects}

This study complied with the ethical precepts of research involving human beings, according to Resolution 466/12 of the National Health Council. All participants signed the Free and Informed Consent Form (FICF). The research was approved by the Research Ethics Committee of the Universidade Estadual Vale do Acaraú (REC/ UVA).

\section{Theoretical-methodological framework}

The Humas Needs Theory ${ }^{(9)}$ was used as a theoretical methodological framework. In this approach, needs show the societal character of our needs, whether "individual", "social" or "natural", and it is impossible to separate human needs from corporate life and, therefore, from the historical process.

Therefore, since social health needs and, historically, the potentiality of individuals to modify themselves and their environment in order to qualify life, cannot be disregarded in this process. Therefore, the needs are realized for the individuals of different social classes and cultural aspects e in an unequal way, because unequal is the access to the products that satisfy the needs ${ }^{(9)}$.

\section{Type of study}

The study consisted of a research with a qualitative approach ${ }^{(10)}$ of the exploratory-descriptive type, in which, the aim was to understand experiences in the daily work and health needs attributed by the women interviewed ${ }^{(10)}$.

This is a mater's dissertation cut that is entitled Vida de Maria: necessidades de saúde das mulheres feirantes do Mercado Público. 
It was presented to the Family Health Training Northeast Network (RENASF - Rede Nordeste de Formação em Saúde da Família) and to the Universidade Estadual Vale do Acaraú (UVA)(11).

\section{Methodological procedures}

\section{Study scenario}

The field of study was the Public Market of a municipality in the Northeast of Brazil, whose population is 205529 inhabitants. This place is part of Primary Care, field of activity of the researcher. The equipment has 280 boxes for marketers, 60 boxes for coffee makers and 32 outlets. Its built area totals 5,918.06 $\mathrm{m}^{2}$. In this space, 34 street market saleswomen develop the role of coffee shops. Despite the name "coffee growers", they carry out other activities, in addition to the sale of coffee, such as the sale of meals and snacks to the passerby public.

\section{Data source}

In this way, this group was chosen to carry out the study and, to that end, they composed the sample 15 street market saleswomen, which included the following criteria: to be present at the workplace at the time of the research and to have more than five years in the activity in question, to guarantee the time of knowledge and implication of the work with her health. Four marketers who refused to participate and three who were on health leave were excluded.

\section{Collection and organization of data}

For the production of data, semi-structured interviews were conducted with the marketers, from March to May 2016. The number of participants was determined based on the inclusion and exclusion criteria, and from the analysis of redundancy or repetition of the information, being evidenced from the $15^{\text {th }}$ interview, in which it was no longer justified to include new elements. Therefore, the "saturation point" was related to the depth with which the objectives were reached, as well as the understanding and contextualization of the research object.

The semi-structured interview was guided by a previously elaborated script, outlining the object studied and contemplating, in a timely manner, issues that could make health needs arise such as: insertion in work, ways of life, determinants of health-disease, concept of health, ways of coping with health problems and effectiveness of health services to respond to women's health problems in the study.

It should be noted that the contact with street market saleswomen was facilitated by the approaches already established previously by the researcher in the occasion of health promotion activities developed in the study setting. Thus, interviews took place in the work environment, at the end of the interview, in a warm and harmonious way between the researcher and the interviewee, avoiding embarrassments and interruptions during the conversation that lasted approximately forty minutes. The recordings of the interviews occurred after signing the FICF.

Marketers were identified in the transcriptions of the speeches by the pseudonym "Maria", and to represent them, fifteen names of Marias were used, public women who left their stories of struggles and achievements recorded in the minds of the Brazilian people, from local women to those of national knowledge. The recording of the interviews was authorized, under anonymity guarantee and carried out by means of an audio recorder, being later transferred to a microcomputer and transcribed integrally.

\section{Data analysis}

Regarding the data analysis, the subjects' expressions about the objects of their health needs and their actions, in order to qualify "way of living life", were analyzed in a coherent sequence with the thematic content analysis that predicts: pre-analysis, material exploration, treatment of results, inference, and interpretation ${ }^{(12)}$.

The Health Needs Taxonomy functioned as an instrument capable of listing and describing the perceived needs of street market saleswomen. This taxonomy was built around four concepts: good living conditions; the need for access to health technologies capable of improving or prolonging life; need to be welcomed and have an affective bond between the user; professional health and autonomy and self-care in the "way of living life"(13).

In this logic, comprehensive and interpretive inferences led to the following themes: "Autonomy for the satisfaction of health needs" and "Popular practices in health care". The focus of analysis and discussion is on these points.

\section{RESULTS}

\section{Participant characterization}

The participants of the study were 15 street market saleswomen, with a mean age of 51 years (ranging from 40 to 64 years), with varied schooling. Nine did not complete elementary school; one finished elementary school; three completed high school and two declared themselves illiterate. All of them had children, with female heads of one-parent families. Four women declared per capita income of less than 200 reais and only one with income above $1,000.00$ reais (reais is the Brazilian currency).

The Health Needs Taxonomy ${ }^{(13)}$ was an instrument capable of listing and describing units of meaning submerged in the expressions of the participants, which represented their health needs. This taxonomy consists of four categories: the first addresses the need for good living conditions; the second refers to the need for access to health technologies capable of improving or prolonging life; the third includes the need for an affective bond between the user and the health professional; and the fourth addresses the need for autonomy and self-care in the "way of living life".

This study contemplates two thematic categories whose content reveals that change, in the sense of trying to overcome contradictions in the "way of living life" to meet health needs, for most street market saleswomen, was encouraged by existential and transcendental needs.

\section{Potentialities and challenges for addressing health needs}

Women, for the most part, cited lifestyle changes as challenges to healthier attitudes and personal self-management, such as a balanced diet, reduced working hours and emotional balance in the face of financial problems.

Nevertheless, with regard to food, it is common, in its reports, changes related to behaviors socially recognized as harmful, 
Street market saleswomen: strategies for the recognition of health needs Magalhães AHR, Silva MAM, Parente JRF, Pereira IH, Vasconcelos MIO, Abreu LDP, et al.

linked to the biologicist notion of health. These changes, cited by the participants, are important for health/disease. Nonetheless, they denote the difficulty to decide in health-related situations and the influence of medical-scientific knowledge, reiterated in people's conception of healthy habits of life:

I avoid eating too much. I live using sweetener, a lot of things I do not eat because of diabetes [...] it is because the doctor forbade it, not as much rice, it is just a spoon, a spoon of beans. Nothing, nothing too much, just a little bit. (Maria Esther)

The need for the development of strategies of educational care by nurses, not for the purpose of prescribing a healthy way of life, nor to adapt the demands according to the offered health products or to medicalize the life of the individual, but with potential for the expansion of autonomy, knowledge and empowerment on health and disease.

Women recognize that overloading work hampers living conditions leading to illness. Giving visibility to this need meant, for Maria Bethânia, to overcome the demands imposed by the work. It is important to point out that this woman has a certain autonomy over her work, made possible by the position of owner of the means of production, but market demands could limit this autonomy if she did not move radically to supply this need:

To rest more, to sleep more, to diminish the activities of the work, and that I diminished enough, psychological and physical, right [...] I have greatly reduced my work system to have more health. (Maria Bethânia)

Even when the desire or aspiration for health care is present, it is often insufficient to produce an action. For women, distance from care practices related to culture becomes an aggravating factor, contributing to their not being active in the construction and reconstruction of their health needs. Thus, the daily barriers, recognized by women, for health care, are concrete. They consider the triple working day, the lack of bond and the lack of access to products and services as the main reasons that prevent health care, or what prevents them from having better living conditions:

I am sincere, since I started working, I do not do much for my health [...] I really miss going for walks. (Maria Clara)

It needs time, and it's what we do not have, it's time to take care for our health. (Maria Rita)

In this sense, from the empirical data, it was possible to perceive some movement of the street market saleswomen, in the sense of satisfying new health needs, mainly, as far as the "way of living life". This attitude was apprehended in the speech of a woman who, not caring about the contradictions of her daily life, begins to deal better with this activity and does something concrete to achieve her goal, thereby benefiting her mental health:

What complicates is the accounts, but who should not? Then we have to leave, to smile, because if we stay, it goes into depression. I will not lie, when I'm 100, I'm going to be in the spirit of 15, because if I have, I'll pay, when I have not, I will not pay, only when I have, I'm not too worried, not. (Maria Firmino)
But this movement is still timid among the participants of the research, exposed the relevance of the contradictions present in the culture and in the reality of these, that distance them from "recognizing" their health needs:

My biggest problem is these roles that I owe [...] what is harming my health is these papers to pay, I worry about these accounts because I have no one to help me. (Maria Paula)

Because it is a human need. Like every need, it is limited by the possibilities of the subjects to objectify them. These limits are manifested in different ways in each individual. What will differentiate it is the ability to recognize actors in their own lives and the need to overcome conditions imposed by the social context in which they are inserted.

\section{Popular practices in health care}

The street market saleswomen seek different care alternatives in response, through beliefs such as faith and home remedies, strategies recognized as practices in health care. The alternative in informal health care used to solve their health problems is holy water, considered as a precious instrument instituted by the Church. This water helps them in some circumstances and difficulties of life, and cultivate the practice of using natural herbs, opting for conventional medicine only in extreme cases, as the following speeches state:

I almost do not go to the health center, I do not go to a doctor, I do not self-medicate, but when I have a headache, I drink holy water and goes away. (Maria Bethânia)

I'm not a doctor all the time, I have my medicines that I do for diabetes, I go there and buy my roots and make my medicine [...] I'm not much of a pharmacy-medicine person, no. I'm more than going there at the root doctor, Mr. X, I take medicine and I get better. (Maria Firmino)

There is evidence of appreciation and respect for religious issues, as they are seen as a health benefit and a way of coping with their needs. In this way, having faith and believing in something transcendental is an essential condition of life, contributing to your health and well-being. When they find themselves in difficult situations, feeling incapable and insecure, approaching their beliefs provides comfort and comfort.

It is believed that, based on the understanding or conception of women regarding what is health-disease, when their health needs are not met in the health services, they seek different care alternatives in response, as we have seen in the previous speeches, through faith and home remedy.

Nonetheless, these alternatives are not common to all street market saleswomen, since they distinguish themselves from the understanding of health and disease, the beliefs they profess and the way they produce their lives.

\section{DISCUSSION}

Dialogically speaking, some of the street marketers referred to the concept of autonomy as the institution of new habits of life that improve their capacity for adaptation and survival in the 
world. From the accumulation of small modifications at the singular level, through the action of the subjects in nature, modifying it and itself, it is possible to initiate processes to overcoming the contradictions of this reality ${ }^{(14)}$.

However, it is understandable that overcoming these barriers depends not only on the ability of individual subjects to mobilize, but also on a social restructuring that requires integration of health policies that increase the equity and universality of health care to other sectors of society relevant to decisions. In addition, the formulation of actions that may impact on working conditions, living conditions and gender social behaviors ${ }^{(15)}$. In this way, the health work must develop in the user an increase of its autonomy, leading it to recognize its needs and to perceive itself as an individual, able to formulate its choices in its "way of living life"(13).

In the formulation of health programs, the participation of the main actors who are also involved in the process that is the user himself is not taken into account. It is praised for the technical rigor of the actions, seeking to objectify the demand brought as a disease, making it real. The subjective issues of users directly involved are left out. This is because what is thought to be the ideal, by technicians and professionals, does not always correspond to the actual situation of the population ${ }^{(16)}$.

For a need to exist, in fact, the subject must necessarily interact with the objects of this need. Unacknowledged, or "unconscious" needs are those that are not, in fact, present to a group or individual. They are called radicals when, to satisfy them, subjects who are aware of them and express radical knowledge, need to make profound changes in their "way of living life"(9).

One of the sets of human needs relates to the need each person has, to have increasing degrees of autonomy in her "way of living life". In view of the health needs of street market saleswomen, health education can be verified as a light technology of care will help women in building their autonomy, and the senses of their lives would have an effective weight in their living and the search for satisfaction of their health needs ${ }^{(6)}$.

Nevertheless, health education practices have been less widespread in collective health actions. Predominantly, these are not educational, being conducted only from a technical or biological point of view, in a tax form, with ready recipes and standard lifestyles. Leading the user to individual empowerment, establishes a better relationship with their health, leading them to a greater awareness in the decision-making about the care they need, developing autonomy in the choices that they deem important in their life ${ }^{(17)}$.

In this study setting, the popular practices in health in the daily life of the street market saleswomen were symbolically observed, with the experiments and uses of tea, holy water and medicinal plants. The concept of "popular health practices encompasses any form of healing that is not properly biomedical, encompassing practices from popular culture, such as blessing and religions"(18). Therefore, these women seek support not only in biomedical professionals, but also in the agents of popular practices, in order to cope with illness situations.

Street market saleswomen, on a regular basis, find it difficult to access formal health services, and are more accessible to popular care practices for solving their problems. On this issue, the World Health Organization (WHO) estimates that $85 \%$ of the world's population makes use of medicinal plants for health care; and $80 \%$ of people in developing countries rely on popular practices for health maintenance or recovery ${ }^{(19)}$.

In addition to its therapeutic character, the use of medicinal plants has relevance in Anthropology, through the rescue of popular wisdom. Moreover, it elevates the self-esteem of populations, often marginalized. The use medicinal plants have a pedagogical methodology, since it allows the establishment of a dialogical relationship between health workers and users who dominate the uses of these medicinal plants, besides the reduced economic value, enable access to the herbal medicine. Finally, the ecology of the species is valued, guaranteeing the maintenance of plants that, in many situations, are being eliminated by the plantations, with a purely lucrative interest ${ }^{(20)}$.

In this sense, it is noticed that the Community Health Agent, being part of the same social group as users, is the professional that has a greater incorporation of the popular knowledge. Thus, other professionals also need to establish a sharing between popular and scientific knowledge, to establish dialogue and proximity with users, with a view to making health practices more effective ${ }^{(21)}$.

Spirituality is also present in the everyday life of the marketers. When one is seeking explanations about health-disease, spirituality is considered a strategy for coping with the health needs of these women. Therefore, nursing care must understand the spiritual, religious and philosophical dimension of the individual, being considered the basis of the humanization of care, guiding principle of care ethics. Spiritual care represents a great challenge for nursing, and it means humanizing; listen carefully and understand your beliefs and values, allowing you a greater recognition of your needs ${ }^{(22)}$.

In this way, the insertion between health and spirituality and the evidences on the theme, have aroused the attention of the researchers and the academy, increasing the research to understand how such demonstrations are capable of influencing the health and human mind ${ }^{(23-24)}$. In addition, interest in knowledge about the spiritual dimension has been emphasized by researchers, professionals and health students, in national and international research ${ }^{(25-26)}$

Faced with these questions, more research should be done to try to understand these gaps in the therapeutic relationship between professional and patient and to evidence integral care. The approach of spirituality by professionals, because it is an incipient practice, becomes deficient, compromising the understanding of the subjectivity of individuals in health-disease and recognition and coping with their health needs. Therefore, with the incorporation of new evidence, professional practice needs to be reformulated and adapted to the understanding of transcendental dimensions neglected in health care, such as spirituality and religiosity ${ }^{(27)}$.

In this way, health professionals as caregivers, especially nurses, can develop a work with the intention of making women closer to care practices and to transmit knowledge about their possible vulnerabilities. They can encourage them to build new agreements, taking into account the way in which they participate socially. This type of approach can contribute to the fact at women recognize themselves as autonomous and co-responsible 
in the search for radical health needs that cannot be recognized in a world of subordination or superordination.

\section{Study limitations}

The main limitations of the study were related to the fact that the interviews were carried out in the workplace and after work, which may have influenced the responses.

\section{Contributions to Nursing, Health, and Public Policies}

It is believed that the nurse, as the leader of the health teams, and the possible work to be built in Primary Health Care, based on the reception and the bond, has great potential to contribute to these women to become aware of radical needs and develop them with greater autonomy and freedom from the overcoming of contradictions inherent in their culture and social insertion in the means of production and consumption.

This research may also be important for other team members, so that the identification of care needs of the population as well as development of autonomy and emancipation of the individuals begins. Thus, it would contribute to the recognition of women as a caregiver, and health practices in these settings distanced themselves from the social reproduction of life-medicating cultures.

\section{FINAL CONSIDERATIONS}

The results of this research indicate that changes in lifestyle are a challenge for female marketers, as well as personal self-management of balanced diet, working hours, emotional balance and financial problems. Strategies for recognizing the health needs of these women are also shown as therapeutic choices that combine elements of the various subsystems, such as popular practices and therapeutic resources of biomedicine, revealing an intersection of knowledge.

Moreover, nursing professionals must take into account the reality of life, work and recognition of the health needs of these women, developing practices aimed at the satisfaction of perceived needs. However, for these practices to be effective, nurses must be familiar with their daily lives, their work activity, and the implications that "being street salesperson" brings to care for themselves. To problematize this reality, to clearly define health needs and to seek resources that will allow the adoption of measures will contribute to the improvement of the living conditions of these women.

It's worth pointing out that social, economic and cultural aspects, as well as individuality of each woman, are elements that should guide the development of practices that bring about change and contribute to satisfy and develop the public health needs of street market saleswomen.

In this context, nursing has the potential to assist the health team in a better approximation of reality, in the needs, potentialities, working conditions, through strategies of prevention, health promotion and understanding of the meanings alluded to by street market saleswomen, when considering knowledge, cultural values, and lifestyles. Moreover, it contributes to the recognition and coping of the health needs of this public, often invisible by the formal segments of health.

\section{REFERENCES}

1. Del Priore M, Pinsky CB. História das Mulheres no Brasil. 10. ed. São Paulo, SP: Contexto; 2015.

2. Vedana V. Fazer a feira e ser feirante: a construção cotidiana do trabalho em mercados de rua no contexto urbano. Horiz Antropol [Internet]. 2013 [cited 2017 May 29];19(39):41-68. Available from: http://www.scielo.br/pdf/ha/v19n39/v19n39a03.pdf

3. Carvalho RG; Oliveira IA; Maia LM; Maciel RH; Matos TR. Situações de trabalho e relato de dor entre feirantes de confecções. Revista psicologia organização e Trabalho. [Internet]. 2016 [cited 2018 May 28];(3):274-84. Available from: http://pepsic.bvsalud.org/scielo. php?script=sci_arttext\&pid=S1984-66572016000300006

4. Carvalho JJ, Aguiar MGG. Qualidade de vida e condições de trabalho de feirantes. Rev Saúde Col UEFS [Internet]. 2017 [cited 2018 May 28];7(3):60-5. Available from: http://periodicos.uefs.br/ojs/index.php/saudecoletiva

5. Berlinguer G. A doença. São Paulo, SP: Hucitec; 1988.

6. Pinheiro R, Mattos RA, (Orgs). Os sentidos da integralidade na atenção e no cuidado à saúde. Rio de Janeiro, RJ: UERJ IMS: ABRASCO, 2006. 184p.

7. Carvalho RG, Oliveira IA, Maia LM, Maciel RH, Matos TR. Situações de trabalho e relatos de dor entre feirantes de confecções. Rev Psicol Org Trab [Internet]. 2016 [cited 2017 Apr 10];16(3):274-84. Available from: http://pepsic.bvsalud.org/scielo.php?script=sci_abstract\&pid $=$ S1984-66572016000300006

8. Silva SRA, Amorim RC, Almeida AM. Percepção de feirantes hipertensos sobre o adoecer crônico. Rev Enferm UERJ [Internet]. 2015 [cited 2017 Feb 21];23(6):761-6. Available from: http://www.facenf.uerj.br/v23n6/v23n6a07.pdf

9. Heller A. Teoría de las necessidades em Marx. 2. ed. Barcelona: Península; 1986.

10. Minayo MCS. O desafio do conhecimento: pesquisa qualitativa em saúde. 14a ed. Rio de Janeiro: Hucitec; 2014.

11. Magalhães AHRM. Vida de Maria: necessidades de saúde das mulheres feirantes do mercado público [Dissertação]. Universidade Estadual Vale do Acaraú, Sobral, 2017 [cited 2017 Jan 13];144. Available from: https://renasf.fiocruz.br/sites/renasf.fiocruz.br/files/disseracoes/2016 UVA_Ana\%20Hirley\%20Rodrigues\%20Magalh\%C3\%A3es_0.pdf

12. Bardin L. Análise de conteúdo. São Paulo, SP: Edições 70; 2015.

13. Cecílio LCO, Matsumoto NF. Uma taxonomia operacional de necessidades de saúde. In: Pinheiro R, Ferla A, Mattos R, (Org.). Gestão em redes: 
tecendo os fios da integralidade em saúde. Rio de Janeiro: Abrasco; Caxias do Sul: Educs, 2006, p. 37-50.

14. Konder LH. O que é dialética. 28. Ed. São Paulo, SP: Brasiliense; 2012.

15. Storino LP, Souza KV, Silva KL. Necessidades de saúde de homens na atenção básica: acolhimento e vínculo como potencializadores da integralidade. Esc Anna Nery [Internet]. 2013 [cited 2017 Sep 11]; 17 (4): 638-45. Available from: http://www.scielo.br/pdf/ean/v17n4/14148145-ean-17-04-0638.pdf

16. Souza CR, Botazzo C. Construção social da demanda em saúde. Physis [Internet]. 2013 [cited 2017 Jul 22]; 23(2): 394-413. Available from: http://www.scielo.br/pdf/physis/v23n2/v23n2a05.pdf

17. Salci MA, Maceno P, Rozza SG, Silva DMGV, Boehs AE, Heidemann ITSB. Educação em saúde e suas perspectivas teóricas: algumas reflexões. Texto Contexto Enferm [Internet]. 2013 [cited 2017 Feb 11];22(1):224-30. Available from: http://www.scielo.br/pdf/tce/v22n1/pt_27.pdf

18. Oliveira MW, Moraes JV. Práticas populares de saúde e a saúde da mulher. Rev APS [Internet]. 2010 [cited 2017 Oct 09];13(4):412-20. Available from: https://aps.ufff.emnuvens.com.br/aps/article/viewFile/723/387

19. Souza CMP, Brandão DO, Silva MSP, Palmeira AC, Simões MOS, Medeiros ACD. Utilização de plantas medicinais com atividade antimicrobiana por usuários do serviço público de saúde em Campina Grande - Paraíba. [Internet]. 2013 [cited 2018 May 28]; 15(2): 188-93. Available from: http://www.scielo.br/pdf/rbpm/v15n2/04.pdf

20. Gomes LB, Merhy EE. Compreendendo a Educação Popular em Saúde: um estudo na literatura brasileira. Cad Saúde Pública [Internet]. 2011 [cited 2017 Mar 15];27(1):7-18. Available from: http://www.scielo.br/pdf/csp/v27n1/02.pdf

21. Acioli S, Kebian LVA, Dias JR, Corrêa VAF, Daher DV, Martins ALX. Scientific and popular knowledge in Family Health Strategies from a hermeneutic-dialectic perspective. O Braz J Nurs [Internet]; 2016[cited 2018 May 28];15(4):644-54. Available from: http://www.objnursing. uff.br/index.php/nursing/article/view/5465

22. Pinto AC, Marchesini SM, Zugno Pl, Zimmermann KG, Dagostin VS, Soratto MT. A importância da Espiritualidade em pacientes com câncer. Rev Saúde Com [Internet]. 2015 [cited 2018 May 26];11(2):114-22. Available from: http://www.uesb.br/revista/rsc/v11/v11n2a02.pdf

23. Rossato K, Backes DS, Costenaro RGS, Zamberlan, C. A dimensão espiritual do cuidado de enfermagem: revisão narrativa. In: Sousa FGM, Backes DS, (Org.). Cuidado em Enfermagem e Saúde: diversidades e complexidade. Florianópolis: Papa-Livro, 2015. p. 37-56.

24. Schiavon AB, Muniz RM, Azevedo NA, Cardoso DH, Matos MR, Arrieira ICO. Profissional da saúde frente a situação de ter um familiar em cuidados paliativos por câncer. Rev Gaúcha Enferm [Internet]. 2016[cited 2018 May 28];37(1):e55080. Available from: http://www.scielo.br/ pdf/rgenf/v37n1/0102- 6933-rgenf-1983-144720160155080.pdf

25. Lavorato-Neto G, Rodrigues L, Turato ER, Campos CJG. The free spirit: spiritualism meanings by a Nursing team on psychiatry. Rev Bras Enferm. 2018;71(2):280-288. doi: http://dx.doi.org/10.1590/0034-7167-2016-0428

26. Naraynasamy A. The challenges of teaching and learning spirituality in Nursing. J Nurs Care [Internet]. 2014 [cited 2018 May 28];3(5):189. Available from: https://www.omicsgroup.org/journals/thechallenges-of-teaching-and-learningspirituality-in-nursing-2167-1168-3-189.pdf

27. Bezerra SMMS, Gomes ET, Galvão PCC, Souza KV. Spiritual well-being and hope in the preoperative period of cardiac surgery. Rev Bras Enferm. 2018; 71(2):398-405. doi: http://dx.doi.org/10.1590/0034-7167-2016-0642 